\title{
Role of non-coding RNAs in maintaining primary airway smooth muscle cells
}

\author{
Mark M Perry ${ }^{1 *}$, Eleni Tsitsiou², Philip J Austin', Mark A Lindsay ${ }^{2,3}$, David S Gibeon ${ }^{1}$, lan M Adcock and Kian Fan Chung ${ }^{1}$
}

\begin{abstract}
Background: The airway smooth muscle (ASM) cell maintains its own proliferative rate and contributes to the inflammatory response in the airways, effects that are inhibited by corticosteroids, used in the treatment of airways diseases.

Objective: We determined the differential expression of mRNAs, microRNAs (miRNAs) and long noncoding RNA species (IncRNAs) in primary ASM cells following treatment with a corticosteroid, dexamethasone, and fetal calf serum (FCS).

Methods: mRNA, miRNA and IncRNA expression was measured by microarray and quantitative real-time PCR.

Results: A small number of miRNAs (including miR-150, -371-5p, -718, -940, -1181, -1207-5p, -1915, and $-3663-3 p$ ) were decreased following exposure to dexamethasone and FCS. The mRNA targets of these miRNAs were increased in expression. The changes in mRNA expression were associated with regulation of ASM actin cytoskeleton. We also observed changes in expression of IncRNAs, including natural antisense, pseudogenes, intronic IncRNAs, and intergenic IncRNAs following dexamethasone and FCS. We confirmed the change in expression of three of these, LINC00882, LINC00883, PVT1, and its transcriptional activator, C-MYC. We propose that four of these lincRNAs (RP11-46A10.4, LINC00883, BCYRN1, and LINC00882) act as miRNA 'sponges' for 4 miRNAs (miR-150, -371-5p, -940, -1207-5p).

Conclusion: This in-vitro model of primary ASM cell phenotype was associated with the regulation of several ncRNAs. Their identification allows for in-vitro functional experimentation to establish causality with the primary ASM phenotype, and in airway diseases such as asthma and chronic obstructive pulmonary disease (COPD).
\end{abstract}

Keywords: Lung disease, Dexamethasone, Transcriptome, Long noncoding RNA, microRNA

\section{Introduction}

Airway smooth muscle cells (ASMCs) are an integral part of the airways (from large to small) and contribute to the airflow obstruction in chronic airway respiratory diseases such as asthma and chronic obstructive pulmonary disease (COPD) through its contractile properties that lead to airway narrowing. In addition, ASM cells are in a state of increased proliferation due to the effect of growth factors that lead to an increase in ASM mass in these diseases [1-4]. Furthermore, they are pro-inflammatory, releasing many cytokines and chemokines $[5,6]$. The regulation of the contractile and proliferative responses of

\footnotetext{
* Correspondence: m.perry@imperial.ac.uk

${ }^{1}$ Experimental Studies, National Heart and Lung Institute, Imperial College, London \& Royal Brompton NIHR Biomedical Research Unit, Dovehouse Street, London SW3 6LY, UK

Full list of author information is available at the end of the article
}

ASM in disease remains unclear. In order to understand this, we have examined the potential contribution of noncoding RNA in these processes in ASM cells.

We have recently found that the proliferation and increased release of IL-6 found in ASM cells from patients with asthma was under the negative regulation of cyclin inhibitors, $\mathrm{p} 21^{\mathrm{WAF} 1} \& \mathrm{p} 27^{\mathrm{kip} 1}$, which were controlled by the microRNA; mir-221 [7]. We hypothesized that other miRNAs may also be involved in other aspects of ASM function. In addition to the miRNA family of short noncoding RNAs that consist of less than 200 nucleotides, there is now accumulating evidence that long noncoding RNAs (lncRNAs with more than 200 nucleotides) can regulate multiple biological responses and that changes in their expression may be related to the development of disease $[8,9]$. 
There are a surprisingly few studies demonstrating the importance of miRNAs in ASM function (Extensively reviewed in [10]) and these only validate the importance of a handful of miRNAs; let-7a, miR-16, miR-25, miR-26a, miR-133, miR-143, miR-145, miR-146a and miR-206. Furthermore, there are currently, no studies examining the roles of IncRNAs in ASM. Therefore, we have adopted a transcriptomic approach to investigate the differential expression of mRNAs, miRNAs and lncRNAs in primary ASM cells and exposed them to a known inducer of proliferation, fetal calf serum (FCS), and also examined the effect of the corticosteroid, dexamethasone.

\section{Methods}

\section{Patient recruitment}

Healthy subjects with no previous history of disease were recruited. Each subject underwent a fiberoptic bronchoscopic study under sedation with midazolam and topical anaesthesia to the airways with lidocaine. Airway biopsies were taken from segmental and sub-segmental airways of the right lower lobe. This study was approved by the Royal Brompton \& Harefield NHS Trust Ethics committee and all subjects gave written informed consent. Subject data are shown in Table 1.

\section{ASM cell culture and stimulation}

ASM cells were picked from bronchial biopsies and cultured in Dulbecco's Modified Eagles Medium (DMEM) supplemented with $4 \mathrm{mM}$ L-glutamine, $20 \mathrm{U} / \mathrm{l}$ of penicillin, $20 \mu \mathrm{g} / \mathrm{ml}$ streptomycin, and $2.5 \mu \mathrm{g} / \mathrm{ml}$ amphotericin B and $10 \%$ foetal calf serum (FCS), as previously described $[7,11]$. At confluence, ASM cell cultures exhibited a typical "hill-and-valley" appearance. Immunofluorescence techniques for calponin, smooth muscle $\alpha$-actin and myosin heavy chain revealed that $>95 \%$ of the cells displayed the characteristics of smooth muscle cells in culture. Cells

\section{Table 1 Subject data}

\begin{tabular}{|c|c|}
\hline$n$ & 9 \\
\hline Age (yrs.) & $36.4 \pm 12.7$ \\
\hline $\operatorname{sex}(\lambda / q)$ & $7 / 2$ \\
\hline Smoking history & 0 \\
\hline Atopy $(n)^{*}$ & 0 \\
\hline Receiving medications ( $n$ ) & 0 \\
\hline $\mathrm{FEV}_{1}(\mathrm{~L})$ & $4.02 \pm 0.48$ \\
\hline $\mathrm{FEV}_{1}(\%$ Predicted) & $104.23 \pm 7.28$ \\
\hline $\mathrm{FEV}_{1} / \mathrm{FVC}(\%)$ & $78.89 \pm 5.98$ \\
\hline$P C_{20}(\mathrm{mg} / \mathrm{ml})$ & $>16$ \\
\hline \multicolumn{2}{|c|}{$\begin{array}{l}\text { FEV }{ }_{1} \text {, forced expiratory volume in } 1 \mathrm{~s} ; \mathrm{FVC} \text {, forced vital capacity; } \mathrm{PC}_{20}, \\
\text { provocative concentration of methacholine causing a } 20 \% \text { fall in } \mathrm{FEV}_{1} ; \mathrm{N} / \mathrm{A} \text { : } \\
\text { not available. *Defined as positive skin prick tests to one or more common } \\
\text { aeroallergens. Data shown as mean } \pm \text { SEM. }\end{array}$} \\
\hline
\end{tabular}

at passages 3-4 were used for all experiments, from 9 different donors.

Confluent cells were growth-arrested by FCS deprivation for $24 \mathrm{~h}$ in DMEM supplemented with sodium pyruvate (1 $\mathrm{mM})$, L-glutamine (2 $\mathrm{mM})$, nonessential amino acids (1:100), penicillin $(100 \mathrm{U} / \mathrm{ml}) /$ streptomycin $(100 \mu \mathrm{g} / \mathrm{ml})$, amphotericin B $(1.5 \mu \mathrm{g} / \mathrm{ml})$, and bovine serum albumin $(0.1 \%)$. Cells were pre-treated with dexamethasone $\left(10^{-7} \mathrm{M}\right)$ for $1 \mathrm{~h}$, before being stimulated with $2.5 \%$ FCS for $24 \mathrm{~h}$. Supernatants were removed and IL-6 and CXCL8 levels determined by DuoSet ELISA (R\&D Systems). Cell proliferation was measured by the Cell Proliferation ELISA BrdU kit (Roche Applied Science), an assay comparable to cell counting as confirmed by flow cytometry $[7,11]$. Cellular viability was assessed by MTT assay [12]. Each patient sample was replicated over 3 wells.

\section{RNA extraction}

Total RNA was extracted using the mirVana ${ }^{\mathrm{Tm}}$ miRNA isolation kit (Ambion Europe). RNA was eluted in $50 \mu \mathrm{l}$ RNase-free water (Promega UK, Southampton, UK) and stored at $-80^{\circ} \mathrm{C}$. RNA content and purity was measured using a BioTek PowerWave XS (SSi Robotics, Tustin, CA, U.S.A.) spectrophotometer.

\section{Microarray analysis}

LncRNA and mRNA expression was determined using the Agilent SurePrint G3 Human GE microarrays and miRNA expression was determined using Agilent Human miRNA microarray following the manufacturer's instructions.

Total RNA samples (50 ng) used in lncRNA and mRNA microarrays were initially labeled with Spike-In control A (for Cyanine 3-CTP) or B (for Cyanine 5-CTP). Labelled samples were then used for cDNA synthesis using the cDNA Master Mix (Agilent) and were incubated for $2 \mathrm{~h}$ at $40^{\circ} \mathrm{C}$ followed by $15 \mathrm{~min}$ at $70^{\circ} \mathrm{C}$ to inactivate the AffinityScript enzyme. The synthesized cDNA was then used for cRNA synthesis and amplification using the Transcription Master Mix with either Cyanine 3 or Cyanine 5 and incubated at $40^{\circ} \mathrm{C}$ for $2 \mathrm{~h}$.

Labeled and amplified RNA was then purified using the RNeasy Mini Kit (Qiagen) and quantified using the NanoDrop Spectrophotometer's Microarray Measurement function. The Cyanine 3 or Cyanine 5 concentrations and the cRNA concentration were used to calculate the yield $(\mu \mathrm{g})$ and the specific activity (pmol Cy3 or Cy5 per $\mu \mathrm{g}$ cRNA) of each sample. For each microarray reaction, 300 ng of Cyanine 3- and 300 ng of Cyanine 5-labelled, linearly amplified cRNA samples were mixed and incubated together with Fragmentation buffer for $30 \mathrm{~min}$, followed by the addition of Hybridization buffer. Samples were loaded onto SurePrint G3 $(8 \times 60 \mathrm{~K})$ microarray slides (Agilent) and hybridized at $65^{\circ} \mathrm{C}$ for $17 \mathrm{~h}$ at $10 \mathrm{rpm}$ using Agilent's Hybridization oven and SureHyb chamber. 
The microarrays were then disassembled and washed in GE Wash Buffer 1 (Agilent) for $60 \mathrm{sec}$ at RT, followed by GE Wash Buffer 2 for $60 \mathrm{sec}$ at $37^{\circ} \mathrm{C}$, followed by an acetonitrile wash (10 sec at RT) and the final wash in Stabilization and Drying solution for $30 \mathrm{sec}$ at RT, to improve microarray results by preventing ozone-mediated fluorescent signal degradation. The microarrays were scanned with the Agilent Microarray Scanner G2565BA using the profile for 2-colour microarrays (AgilentG3 GX_2Color) at $5 \mu \mathrm{m}$ resolution, dyes channel Red\&Green, Scan Area $61 \times 21.6 \mathrm{~mm}$.

miRNA-enriched RNA samples (100 ng) used in the microRNA microarrays were labeled with the Labeling Spike-In solution using Agilent's miRNA Complete Labeling and Hyb Kit and then the samples were dephosphorylated by incubation at $37^{\circ} \mathrm{C}$ on a heat block for $30 \mathrm{~min}$. DMSO was added to the dephosphorylated RNA for denaturation for $10 \mathrm{~min}$, followed by the assembly of the Labeling Reaction, where samples were incubated with Cyanine 3-pCp and allowed to ligate for $2 \mathrm{~h}$ at $16^{\circ} \mathrm{C}$. The labeled RNA was purified using Micro Bio-Spin 6 columns (Bio-Rad) and the desalted samples were dried up in a vacuum concentrator at $50^{\circ} \mathrm{C}$ for $1 \mathrm{~h}$ to remove DMSO. Samples were resuspended in Hybridization Mix using Hyb Spike-In solution and Hybridization Buffer and were loaded onto Agilent Human miRNA microarrays and hybridized at $55^{\circ} \mathrm{C}$ for $20 \mathrm{~h}$ at $20 \mathrm{rpm}$ using Agilent's Hybridization oven and SureHyb chamber. The microarrays were then disassembled and washed in GE Wash Buffer 1 (Agilent) for $60 \mathrm{sec}$ at RT, followed by GE Wash Buffer 2 for $60 \mathrm{sec}$ at $37^{\circ} \mathrm{C}$. The microarrays were scanned with the Agilent Microarray Scanner G2565BA using the profile for miRNA microarrays (AgilentHD_ miRNA) at $2 \mu \mathrm{m}$ resolution, dye channel Green, Scan Area $61 \times 21.6 \mathrm{~mm}$.

Following normalization against internal controls provided within the labeling kits, probes which had background expression (signal value of mRNA $<4.5$ and miRNA < 5.0) were removed. The threshold of background expression was determined using samples that processed but which contained no RNA. Since initial analysis of mRNA, lncRNA and miRNA between baseline and FCS-treated cells or dexamethasone + FCS-treated cells showed none that gave a FDR $<0.1$, differential expression ( $p$ value) was determined by 3-way ANOVA using the Partek Genomics Suite. We report changes in expression with $\mathrm{p}<0.05$. Predicted interactions between miRNAs and mRNA were determined using TargetScan 5.2 within the Partek Genomics Suite. The changes in profile of mRNA expression were analyzed using the bioinformatics database, DAVID $6.7[13,14]$ and possible miRNA-lncRNA interactions, were examined using LNCipedia 2.0 [15]. Microarray data has been deposited at GEO.

\section{Quantitative PCR measurement of miRNA and mRNA expression}

miRNA and IncRNA expression was undertaken with the 2-step Applied Biosystems TaqMan RT-PCR protocol (Applied Biosystems) and normalized to 18S, as previously described $[7,11,16]$. mRNA expression was determined using TaqMan RT-PCR with Assays on Demand (Applied Biosystems). The separate-well $2^{-(\Delta \Delta \mathrm{Ct})}$ method was used to determine relative quantitative levels of individual miRNAs, lincRNAs and mRNAs.

\section{Data and statistical analysis}

The RT-PCR results are presented as the mean \pm SEM of at least nine independent experiments. Statistical analysis was performed by Mann-Whitney U-test test, assuming non-parametric distribution. $\mathrm{P}$ values of $<0.05$ were considered significant.

\section{Results}

\section{Effect of Dexamethasone and FCS upon ASM cell} proliferation, IL- 6 and CXCL8 release

We have previously demonstrated that $2.5 \% \mathrm{v} / \mathrm{v}$ FCS and $10^{-7} \mathrm{M}$ dexamethasone are optimum concentrations to induce and, conversely, inhibit both a pro-inflammatory and proliferative state in primary ASM $[7,11,17]$.

To confirm activation, in this study, of primary ASM by the stimulus (FCS), and pre-treatment with corticosteroid (dexamethasone), we measured DNA synthesis, IL-6, and CXCL8 release by ELISA. At $24 \mathrm{~h}$, FCS (2.5\%) induced DNA synthesis by $\sim 2.5$-fold $(\mathrm{p}<0.001)$, IL-6 release $\sim 3$-fold $(\mathrm{p}<0.001)$ and CXCL8 release $\sim 2$-fold $(\mathrm{p}<0.001)$ (Figure 1A, C \& D). When ASM cells were exposed to dexamethasone $\left(10^{-7} \mathrm{M}\right)$ for $1 \mathrm{~h}$ prior to stimulation with FCS, this increase was completely attenuated ( $\mathrm{p}<0.001$ ) (Figure 1A, C \& D). No effect was observed upon cellular viability (Figure $1 \mathrm{~B}$ ).

\section{Effect of dexamethasone and FCS upon mRNA expression} Following stimulation with FCS (2.5\%) 525 mRNA were increased in expression and 680 were decreased (Additional file 1: Table S1 \& S2). Following treatment with Dexamethasone $\left(10^{-7} \mathrm{M}\right)$ for $1 \mathrm{~h}$ before subsequent stimulation with FCS (2.5\%) 436 mRNA were increased in expression and 457 were decreased (Additional file 1: Table S3 \& S4). Interestingly, only 5 mRNAs were differentially expressed in primary ASM cells after treatment with FCS or dexamethasone + FCS. The pre-treatment of the ASM cells with dexamethasone, prevented the subsequent change induced by FCS as confirmed by RT-PCR (Figure 2 and Table 2). For the first time, we report here the differential expression of these mRNAs in primary ASM cells.

To identify the pathways that these mRNAs are involved in, we analysed the changes in profile of mRNA 

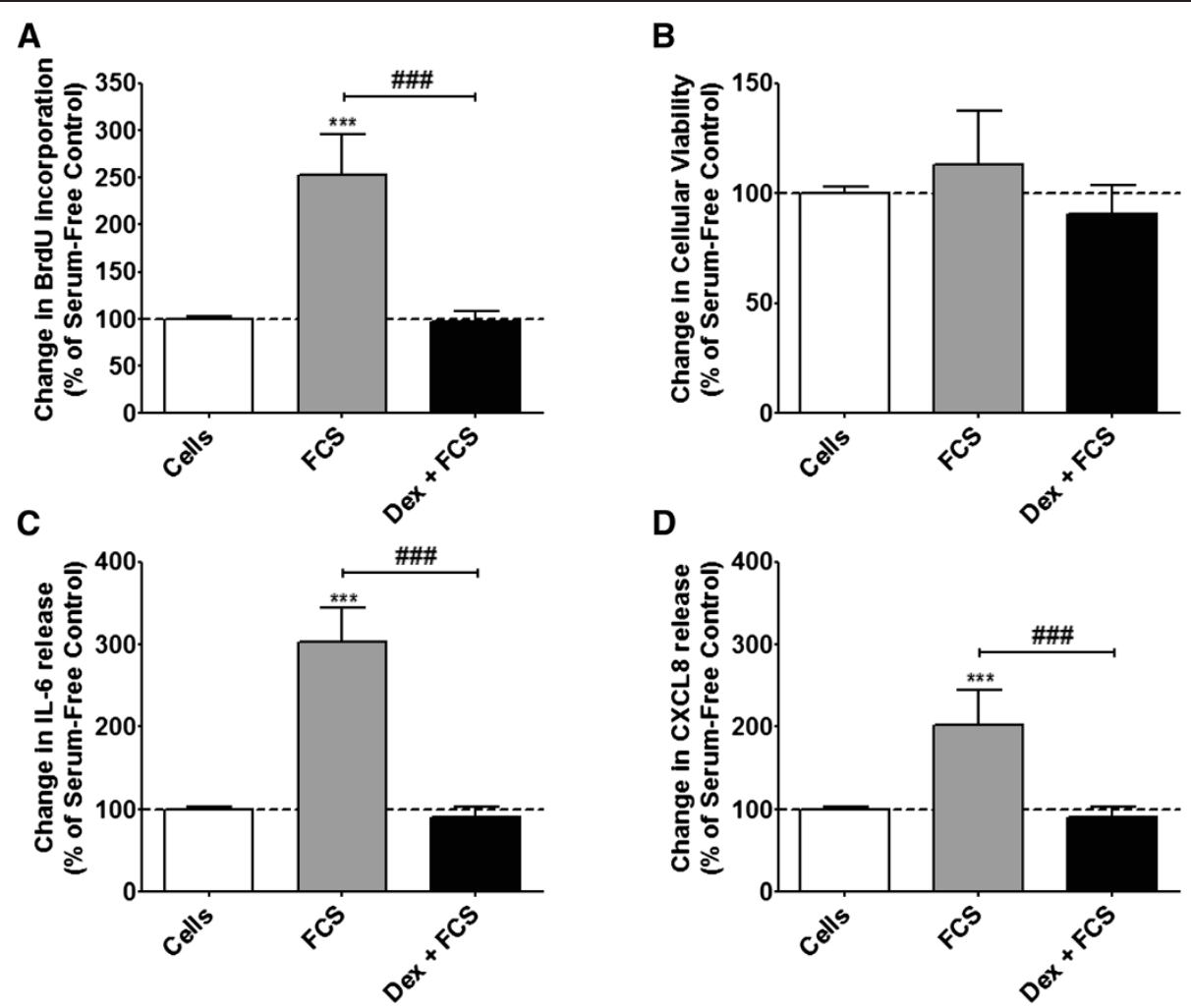

Figure 1 Effect of dexamethasone and FCS upon primary ASM cell proliferation, IL- 6 and CXCL8 release. ASM cells were incubated with dexamethasone $\left(10^{-7} \mathrm{M}\right)$ for $1 \mathrm{~h}$ before being stimulated with FCS (2.5\%) for $24 \mathrm{~h}$. DNA synthesis (A), cell viability (B), IL-6 (C) and CXCL8 (D) release were measured by BrdU ELISA, DuoSet ELISA or MTT assay, respectively. Bars represent mean \pm SEM from 9 primary ASM cells. ***/\#\#\# $\mathrm{p}<0.001$.

expression using the bioinformatics database, DAVID 6.7 (http://david.abcc.ncifcrf.gov/) [13,14]. Significantly, this showed a deregulation of those mRNAs involved in inflammatory and other signalling pathways in primary ASM cells following stimulation with FCS (2.5\%). These included those involved in ASM cell signalling (the NOD- like receptor signalling pathway, cell cycle and p53 signalling pathway) and inflammation (Cytokine-cytokine receptor interaction and the TGF- $\beta$ signaling pathway). Interestingly, when the same ASM cells were pre-treated with dexamethasone $\left(10^{-7} \mathrm{M}\right)$ before being stimulated with FCS $(2.5 \%)$, these pathways were not activated, and

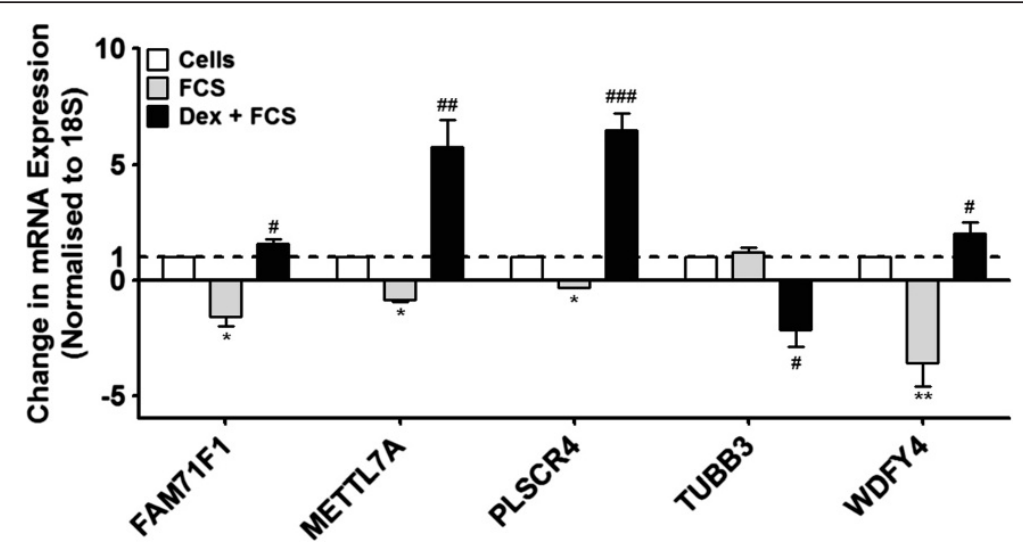

Figure 2 Effect of dexamethasone and FCS upon mRNA expression in primary ASM cells. ASM cells were incubated with dexamethasone $\left(10^{-7} \mathrm{M}\right)$ for $1 \mathrm{~h}$ before being stimulated with FCS $(2.5 \%)$ for $24 \mathrm{~h}$. To validate the array data, the expression of 5 mRNAs were confirmed by TaqMan RT-PCR. Bars represent mean \pm SEM from 9 primary ASM cells. ${ }^{+++} p<0.001$ vs. $185 ;{ }^{* / \#} p<0.05$ vs. baseline; ${ }^{* * / \# \#} p<0.01$ vs. baseline; $\# \mathrm{p}<0.001$ vs. baseline. 
Table 2 Differential mRNA expression changes in healthy ASM cells after treatment with FCS or Dex + FCS

\begin{tabular}{lcccc}
\hline mRNA & \multicolumn{2}{c}{ FCS } & \multicolumn{2}{c}{ Dex +FCS } \\
\cline { 2 - 4 } & Microarray (FC) & qRT-PCR (FC) & Microarray (FC) & qRT-PCR (FC) \\
\hline FAM71F1 & $-1.7(<.05)$ & $-1.62(<.05)$ & $2.1(<.05)$ & $1.56(<.05)$ \\
METTL7A & $-1.9(<.01)$ & $-0.85(<.05)$ & $1.6(<.001)$ & $5.77(<.01)$ \\
PLSCR4 & $-1.5(<.001)$ & $-0.33(<.05)$ & $-1.7(<.001)$ & $6.47(<.001)$ \\
TUBB3 & $1.5(<.05)$ & $1.22(<.05)$ & $1.8(<.05)$ & $-2.18(<.05)$ \\
WDFY4 & $-1.8(<.05)$ & $-3.60(<.01)$ & $2.01(<.05)$ \\
\hline
\end{tabular}

This table lists those mRNAs that were differentially expressed in healthy ASM cells following stimulation with FCS (2.5\%) or treatment with dexamethasone $\left(10^{-7} \mathrm{M}\right)$ before stimulation with FCS $(2.5 \%)$. Microarray data are denoted as the fold change against baseline control and is the mean of 9 individual patients. These values are derived from Additional file 1: Table S1, S2, S3, S4 and are for those genes that demonstrated an FDR of less than 0.05; associated P values are shown in parentheses. FC, Fold change.

instead normal cell function was resumed (e.g. phenylalanine and tyrosine metabolism) (Table 3).

\section{miRNA expression levels in primary ASM cells and their respective targets}

We extracted RNA from ASM cells and measured the expression of the miRNAs. At baseline, we detected 230 miRNAs (Additional file 1: Table S5). Following exposure to FCS (2.5\%), 10 of these were decreased in expression; a further 3 more were decreased in expression when the ASM cells were exposed to dexamethasone prior to addition of FCS (Table 4). We determined the expression of 6 of these miRNAs by RT-PCR and confirmed that the expression of miR-371-5p, -718, -1181, -1207-5p, -1915, and $-3663-3 p$ were reduced by dexamethasone and FCS (Figure 3).

We utilized the miRNA target prediction program TargetScan (http://www.targetscan.org/) to review the targets of these miRNAs. Of the miRNAs decreased in expression following FCS, 3 have predicted mRNA targets that were subsequently increased in expression (Additional file 1: Table S1 \& S3). To identify the pathways

Table 3 Pathway analysis in primary ASM cells

\begin{tabular}{lc}
\hline Gene set name & P-value $^{*}$ \\
\hline 2.5\% FCS & \\
Cell cycle & 0.0045 \\
NOD-like receptor signalling pathway & 0.0046 \\
Cytokine-cytokine receptor interaction & 0.05 \\
P53 signalling pathway & 0.03 \\
TGF- $\beta$ signalling pathway & 0.02 \\
2.5\% FCS + $10^{-7}$ M dexamethasone & \\
Phenylalanine metabolism & 0.011 \\
Tyrosine metabolism & 0.04 \\
\hline
\end{tabular}

Pathway analysis of those mRNAs changed in expression using the bioinformatics database, DAVID 6.7 (http://david.abcc.ncifcrf.gov/). * Modified Fisher Exact P-Value, EASE Score (Maximum Probability). The threshold of EASE Score, a modified Fisher Exact P-Value, for gene-enrichment analysis. Fisher Exact $P$-Value $=0$ represents perfect enrichment. $P$-Value is equal or smaller than 0.05 to be considered strongly enriched in the annotation categories. Default is 0.1 . that these mRNAs are involved in, we analysed the changes in profile of mRNA expression using the bioinformatics database, DAVID 6.7 (http://david.abcc.ncifcrf.gov/) $[13,14]$. This showed that these mRNAs are essential in regulation of the actin cytoskeleton, the remodelling of which is an important mechanism of airway smooth muscle contraction [18]. We confirmed the increased expression of these mRNAs by RT-PCR (Figure 4).

\section{IncRNA expression levels in primary ASM cells}

Long noncoding RNAs may regulate multiple biological pathways that could lead to the development of disease. Currently, lncRNAs can be broadly divided into 4 families based on their sequence and relative position to the exonic regions of protein-coding sequences and include pseudogenes, natural antisense (to exonic regions), intronic lncRNAs, and intergenic lncRNAs [19]. To identify novel lncRNAs, we used ENSEMBLE (www.ensembl.org/ index.html) to determine the genomic position of those probe sets from the microarray that did not match known protein-coding genes.

Following stimulation with FCS, 17 lncRNAs were increased (Additional file 1: Table S6) and 40 lncRNAs were decreased in expression (Additional file 1: Table S7). In the presence of dexamethasone $\left(10^{-7} \mathrm{M}\right)$ and FCS, the lncRNA expression profile changed dramatically with 27 lncRNAs increasing and 39 decreasing in expression (Additional file 1: Tables S8 \& S9, respectively). Interestingly, 29 lncRNAs were altered after FCS and after dexamethasone + FCS (Table 5). We confirmed the increased expression of LINC00882, LINC00883, and PVT1 oncogene by RT-PCR, and found them to be significantly increased in expression in primary ASM cells that had been pre-treated with dexamethasone $\left(10^{-7} \mathrm{M}\right)$, before being stimulated with FCS $(2.5 \%)(\mathrm{P}<0.05)$ (Figure 5). Furthermore, PVT1 is known to be transcriptionally activated by the oncogene c-MYC and p53 both of which were increased in expression in our screen of mRNAs, and we confirmed the expression of c-MYC by RT-PCR, and in a similar pattern to the PVT1 we found it to be significantly increased in expression in primary ASM cells 
Table 4 miRNA expression changes in healthy ASM cells after treatment with FCS or Dex + FCS

\begin{tabular}{|c|c|c|c|c|c|}
\hline \multirow[t]{2}{*}{ miRNA } & \multirow[t]{2}{*}{ Baseline expression $(\Delta C T)$} & \multicolumn{2}{|c|}{ FCS } & \multicolumn{2}{|c|}{ Dex + FCS } \\
\hline & & Microarray (FC) & qRT-PCR (FC) & Microarray (FC) & qRT-PCR (FC) \\
\hline hsa-miR-134 & $6.1(<.001)$ & - & - & $-1.5(<.001)$ & $-1.32(<.05)$ \\
\hline hsa-miR-150* & $6.2(<.001)$ & - & - & $-1.5(<.001)$ & $-1.25(<.05)$ \\
\hline hsa-miR-371-5p & $6.3(<.001)$ & $-1.6(<.001)$ & $-0.97(<.05)$ & $-1.7(<.001)$ & $-1.73(<.05)$ \\
\hline hsa-miR-718 & $5.4(<.001)$ & $-1.5(<.001)$ & $-1.26(<.05)$ & $-1.6(<.001)$ & $-1.44(<.05)$ \\
\hline hsa-miR-762 & $7.6(<.001)$ & $-1.7(<.001)$ & - & $-1.9(<.001)$ & - \\
\hline hsa-miR-940 & $6.7(<.001)$ & $-1.5(<.001)$ & - & $-1.6(<.001)$ & - \\
\hline hsa-miR-1181 & $7.0(<.001)$ & $-1.7(<.001)$ & $-0.89(<.05)$ & $-1.8(<.001)$ & $-0.89(<.05)$ \\
\hline hsa-miR-1207-5p & $7.7(<.001)$ & $-1.8(<.001)$ & $-1.73(<.05)$ & $-2.0(<.001)$ & $-1.13(<.05)$ \\
\hline hsa-miR-1915 & $9.0(<.001)$ & $-1.8(<.001)$ & $-0.58(<.05)$ & $-1.9(<.001)$ & $-0.66(<.05)$ \\
\hline hsa-miR-3663-3p & $8.0(<.001)$ & $-1.8(<.001)$ & $-1.10(<.05)$ & $-2.0(<.001)$ & $-1.36(<.05)$ \\
\hline hsa-miR-3665 & $9.7(<.001)$ & $-2.1(<.001)$ & - & $-2.3(<.001)$ & - \\
\hline hsa-miR-4271 & $6.1(<.001)$ & - & - & $-1.5(<.001)$ & - \\
\hline hsa-miR-4281 & $9.6(<.001)$ & $-1.6(<.001)$ & - & $-1.5(<.001)$ & - \\
\hline
\end{tabular}

This table lists those miRNAs that were differentially expressed in healthy ASM cells following stimulation with FCS (2.5\%) or treatment with dexamethasone (10-7 M) before stimulation with FCS (2.5\%). Baseline expression levels are expressed as $\Delta$ cycle threshold $(\Delta C T)$ and have been normalized against RNU44. Microarray data are denoted as the fold change against baseline control and is the mean of 9 individual patients. These values are for those genes that demonstrated an FDR of less than 0.05 ; associated $P$ values are shown in parentheses. FC, Fold change.

that had been pre-treated with dexamethasone, before being stimulated with FCS $(\mathrm{p}<0.05)$ (Figure 5).

Finally, we reviewed the possibility of some of these expressed lncRNAs acting as miRNA 'sponges', a concept well documented (69). For possible miRNA-lncRNA interactions, we consulted the online database LNCipedia 2.0 (http://lncipedia.org/). We found that 4 lncRNAs were predicted to act as miRNA 'sponges' for miRNAs that were detected in our screen. For example, RP1146A10.4 has complementary regions for miR-1207 (12 sites) and -150 (4 sites). LINC00883 has a binding region for miR-150 (6 sites), BCYRN1 is proposed to be

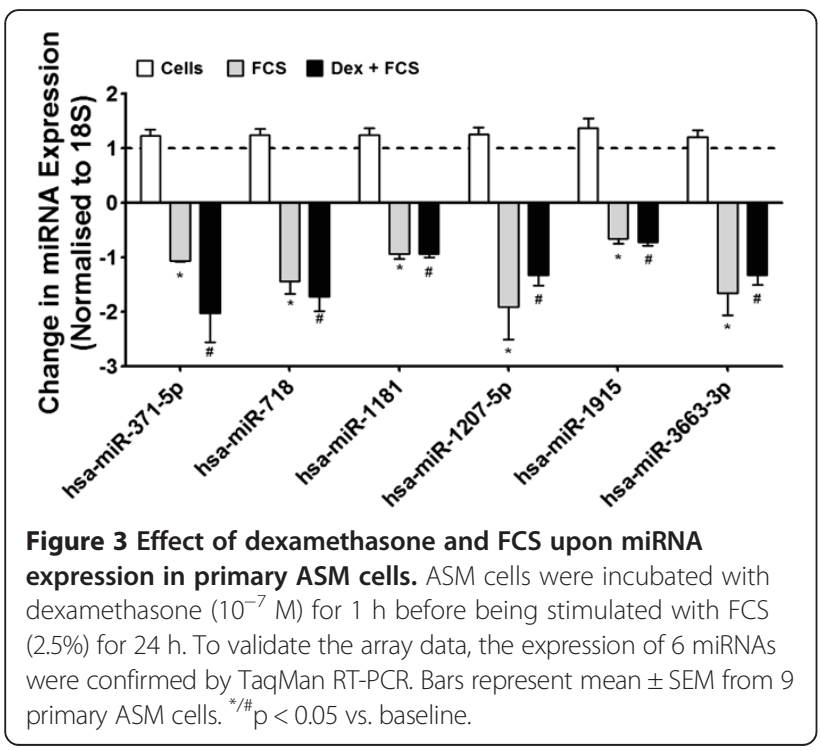

complementary for miR-150 (49 sites), -940 (14 sites) and -371 (18 sites), and LINC00882 is complementary for miR-371 (7 sites). However, to confirm these interactions, subsequent binding studies will need to be undertaken.

\section{Discussion}

We have made several important observations in the expression profiles of non-coding RNAs, including mRNAs, miRNAs and lncRNAs in primary human ASM cells, following stimulation with a well-characterised inducer of proliferation and inflammatory mediator release (FCS), and treatment with a corticosteroid (dexamethasone).

Of all the mRNAs that we examined, only 5 were differentially expressed following treatment. These included a methyltransferase (METTL7A) which is a type of transferase enzyme that transfers a methyl group from a donor to an acceptor, a scramblase (PLSCR4) which is a protein responsible for the translocation of phospholipids between the two monolayers of a lipid bilayer of a cell membrane [20], a member of the tubulin family (TUBB3) which plays a critical role in proper axon guidance and maintenance and is expressed in non-small cell lung cancer [21] and WDFY4, a protein with unknown function but is predominantly expressed in primary and secondary immune tissues [22]. Of those mRNA changed in expression, we have previously reported upon the action of many of these in primary human ASM cells. For example, disintegrin and metalloprotease proteins (ADAMs) inhibit ASM cell adhesion and migration through the $\beta(1)$-integrin [23]. Here, we demonstrate 


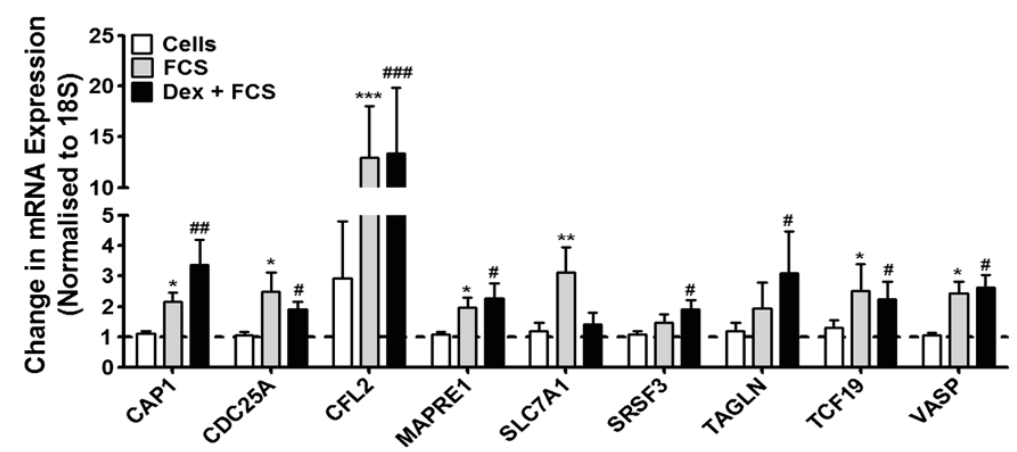

Figure 4 Effect of dexamethasone and FCS upon the predicted mRNA targets of miRNAs decreased in expression in primary ASM cells. ASM cells were incubated with dexamethasone $\left(10^{-7} \mathrm{M}\right)$ for $1 \mathrm{~h}$ before being stimulated with FCS (2.5\%) for $24 \mathrm{~h} .9$ mRNAs were changed in expression following treatment. To validate the array data, the expression of these mRNAs were confirmed by TagMan RT-PCR. Bars represent mean \pm SEM from 9 primary ASM cells. ${ }^{* \#} \mathrm{p}<0.05$ vs. baseline; ${ }^{* * / \# \#} \mathrm{p}<0.01$ vs. baseline; $\# \# \#<0.001$ vs. baseline.

others to be increased in expression after stimulation with FCS (2.5\%) (ADAM19 \& ADAMTS4) (Additional file 1: Table S1), and two more were decreased in expression after stimulation with FCS (2.5\%) (ADAM8 \& ADAMTS10) (Additional file 1: Table S2) and both of these were further decreased in expression when the ASM cells were pre-treated with dexamethasone $\left(10^{-7} \mathrm{M}\right)$ before subsequent stimulation with FCS (ADAM8 \& ADAMTS10) (Additional file 1: Table S4). Furthermore, 4 additional ADAMs were increased in expression when the ASM cells were pre-treated with dexamethasone $\left(\begin{array}{ll}10^{-7} & \mathrm{M}\end{array}\right)$ before subsequent stimulation with FCS (ADAM28, ADAMTS1, ADAMTS4, and ADAMTS9), and the previously up-regulated ADAM19 was further increased in expression (Additional file 1: Table S3). ASM cells pre-treated with dexamethasone $\left(10^{-7} \mathrm{M}\right)$ before subsequent stimulation with FCS resulted in the decreased expression of a further 3 (ADAMTS14, ADAMTS19, and ADAMTSL1) (Additional file 1: Table S4). Furthermore, we have previously demonstrated that CCL11 (Eotaxin), is not only released in higher concentrations from ASM cells of patients with asthma compared to nonasthmatic control subjects, but also that dexamethasone can't repress this release effectively in asthmatic patients [2]. This comprehensive screen of mRNAs shows that CCL11 is decreased in expression in response to FCS stimulation (Additional file 1: Table S2) and pre-treatment with dexamethasone before stimulation results in a further decrease in expression (Additional file 1: Table S4). Interestingly, activation of NF- $\mathrm{KB}$ may be the basis for increased expression of many inflammatory genes and for the perpetuation of chronic airway inflammation in asthma [24]. Once again, we show that 2 mRNAs essential for the de-activation of NF- $\mathrm{kB}$ are decreased in expression following stimulation with FCS. This includes NFKBIE, which binds to components of NF-kappa-B, trapping the complex in the cytoplasm and preventing it from activating genes in the nucleus, and NFKBIZ, involved in regulation of NF- $\mathrm{BB}$ transcription factor complexes (Additional file 1: Table S2). ASM cells are able to express the toll-like receptors, TLR1 to TLR10 via different stimuli. We demonstrated that dexamethasone inhibited cytokine- and ligandinduced TLR2, TLR3, and TLR4 expression and chemokine release. However, dexamethasone potentiated TLR2 expression induced by combined IFN-gamma and TNF-alpha stimulation [25]. Here we see that TLR2 is decreased in expression following stimulation with FCS (Additional file 1: Table S2) and is further reduced when the cells are pre-treated with dexamethasone before said stimulation (Additional file 1: Table S4). Interestingly, TLR4 was increased in expression when the cells are pre-treated with dexamethasone before said stimulation (Additional file 1: Table S3). Additionally, we have previously demonstrated that IRAK-1 mRNA expression is significantly decreased in expression following IL-1 $\beta$ stimulation, in ASM cells [17]. Here we show that ASM cells pre-treated with dexamethasone before stimulation with FCS causes an increase in expression of IRAK1 (Additional file 1: Table S3). Here we demonstrate that FCS induces IL-6 release from primary ASM cells. We have previously found that TGF- $\beta$ induced the expression of NOX4 and was accompanied by elevated IL- 6 release in ASM cells [26]. Further studies revealed a role for SMAD3 pathways. ASM cells treated with dexamethasone, before stimulation with FCS, further increases the expression of NOX4 (Additional file 1: Table S3), and decreases the expression of SMAD3 (Additional file 1: Table S4). Finally, and most recently, we have previously shown that the cyclin-dependent inhibitor p27 $7^{\mathrm{KIP} 1}$ (CDKN1B) is vitally important in driving the hyperproliferation seen in ASM cells from asthmatics [7]. Here we see that cells treated with dexamethasone before stimulation with FCS show a decreased expression in this inhibitor (Additional file 1: Table S4). 
Table 5 Common IncRNA expression changes in healthy ASM cells after treatment with FCS or Dex + FCS

\begin{tabular}{|c|c|c|c|c|}
\hline & & & FCS & Dex + FCS \\
\hline Class of IncRNA & Ensemble gene ID & Transcript & Microarray (FC) & Microarray (FC) \\
\hline Known sense overlapping & ENST00000314957 & CTD-2201E18.3 & $-1.73(<.01)$ & $1.78(<.05)$ \\
\hline $\operatorname{lincRNA}$ & ENST00000414120 & LINC00887 & $-1.81(<.05)$ & $-1.93(<.01)$ \\
\hline Known antisense & ENST00000415647 & RP11-46A10.4 & $-1.62(<.05)$ & $-1.65(<.05)$ \\
\hline lincRNA & ENST00000417485 & AC012668.2 & $-2.28(<.01)$ & $-1.81(<.01)$ \\
\hline lincRNA & ENST00000418539 & BCYRN1 & $-1.53(<.05)$ & $2.37(<.05)$ \\
\hline Known antisense & ENST00000420095 & LMCD1-AS1 & $-1.57(<.05)$ & $5.65(<.05)$ \\
\hline lincRNA & ENST00000426635 & LINC00472 & $1.86(<.05)$ & $2.64(<.05)$ \\
\hline lincRNA & ENST00000431759 & SLC2A1-AS1 & $-1.95(<.05)$ & $-2.09(<.05)$ \\
\hline lincRNA & ENST00000433843 & SNHG5 & $-1.74(<.05)$ & $-1.51(<.01)$ \\
\hline lincRNA & ENST00000442316 & AC074363.1 & $-1.60(<.05)$ & $-1.62(<.05)$ \\
\hline lincRNA & ENST00000444958 & DANCR & $2.59(<.05)$ & $2.38(<.05)$ \\
\hline Known antisense & ENST00000446423 & SDCBP2 & $-1.82(<.05)$ & $-1.82(<.05)$ \\
\hline lincRNA & ENST00000448738 & RP1-295F6.2 & $1.62(<.05)$ & $1.53(<.05)$ \\
\hline lincRNA & ENST00000451910 & RP11-344J7.2 & $2.06(<.01)$ & $1.66(<.05)$ \\
\hline Known retained intron & ENST00000453698 & SNHG11 & $-2.85(<.01)$ & $-2.24(<.01)$ \\
\hline lincRNA & ENST00000473636 & LINC00882 & $2.14(<.05)$ & $2.08(<.05)$ \\
\hline lincRNA & ENST00000495228 & LINC00883 & $1.63(<.05)$ & $1.78(<.05)$ \\
\hline lincRNA & ENST00000505448 & RP11-774O3.3 & $-1.57(<.001)$ & $-1.66(<.05)$ \\
\hline Known antisense & ENST00000507963 & NR2F1-AS1 & $-1.66(<.05)$ & $-1.61(<.05)$ \\
\hline Known antisense & ENST00000509179 & MEF2C-AS1 & $-2.59(<.05)$ & $-2.16(<.01)$ \\
\hline lincRNA & ENST00000515296 & CTB-35F21.1 & $-1.83(<.05)$ & $-1.94(<.05)$ \\
\hline lincRNA & ENST00000515306 & СTB-35F21.2 & $-2.23(<.05)$ & $-2.15(<.05)$ \\
\hline lincRNA & ENST00000515871 & CTC-325J23.3 & $1.60(<.05)$ & $1.72(<.01)$ \\
\hline lincRNA & ENST00000518765 & RP11-527N22.1 & $-1.69(<.05)$ & $-1.53(<.05)$ \\
\hline lincRNA & ENST00000518771 & RP11-37B2.1 & $-1.85(<.001)$ & $-1.71(<.001)$ \\
\hline lincRNA & ENST00000521128 & СТВ-43E15.3 & $-2.07(<.05)$ & $-2.06(<.05)$ \\
\hline lincRNA & ENST00000523242 & CTB-43E15.1 & $-1.79(<.05)$ & $-2.02(<.05)$ \\
\hline $\operatorname{lincRNA}$ & ENST00000523328 & PVT1 & $1.39(<.01)$ & $1.66(<.001)$ \\
\hline lincRNA & ENST00000538996 & AP003486.1 & $-2.69(<.01)$ & $-1.81(<.05)$ \\
\hline
\end{tabular}

This table lists those IncRNAs that have been manually annotated in the Ensembl database and the expression of which is significantly changed in healthy ASM cells after stimulation with FCS $(2.5 \%)$ or treatment with dexamethasone $\left(10^{-7} \mathrm{M}\right)$ before stimulation with FCS $(2.5 \%)$. Microarray data are denoted as the fold change against baseline control and is the mean of 9 individual patients. These values are for those genes that demonstrated an FDR of less than 0.05 ; associated $P$ values are shown.

We then proceeded to measure the expression of miRNAs in our human primary ASM cells. Over 200 miRNAs were detected, and we detected a change in the expression of a handful of these miRNAs following subsequent stimulation with FCS and treatment with dexamethasone. All of these miRNAs have previously been shown to be associated with cancer, for example, miR-371-5p is associated with gastric cancer [27], miR-718 with breast cancer [28], miR-1181 with ovarian cancer [29], miR-1207-5p is associated with a novel cancer treatment, isoliquiritigenin [30], miR-1915 is associated with drug resistance in colorectal cancer [31] and miR-3663-3p is associated with skin cancer [32]. Although these miRNAs have a role in aberrant cellular proliferation, this is the first time that these miRNAs have reported to be expressed in proliferating primary ASM cells. However, miR-1915 and -1207 have been previously reported to be increased in expression in asthmatic epithelial cells from airway brushings [33], and miR-1207 has been shown to be associated with vascular smooth muscle proliferation [34]. Furthermore, we propose that the decreased expression of three of these miRNAs (miR-371-5p, -940 and $-1207-5 p$ ), allows for the expression of their target mRNAs which are involved in critical aspects of ASM 
LINC00882

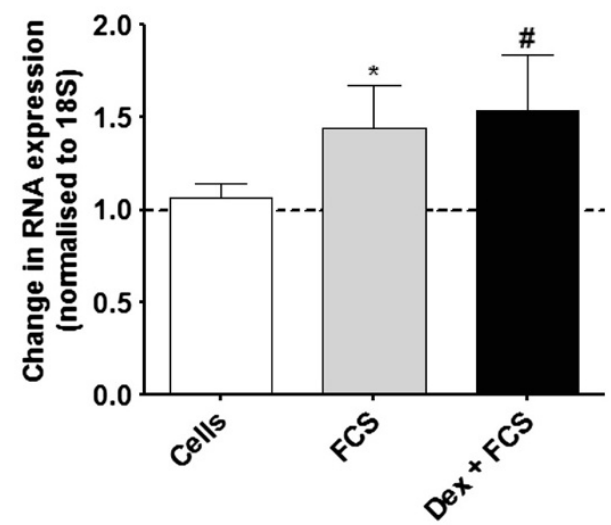

C-MYC

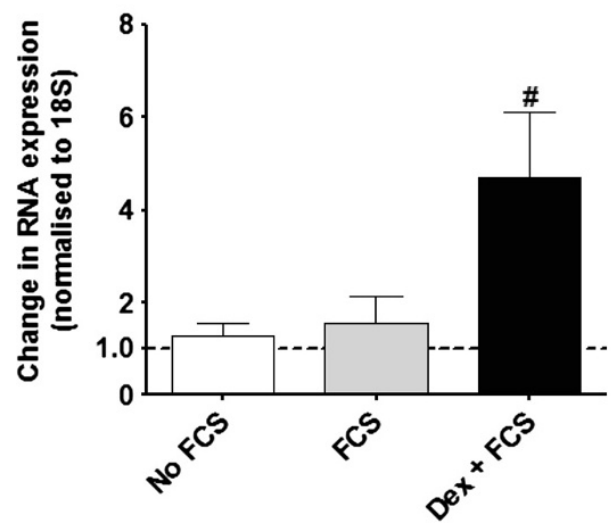

LINC00883

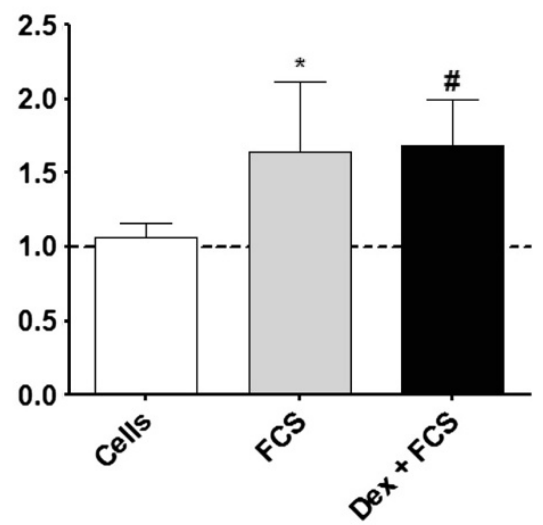

PVT1

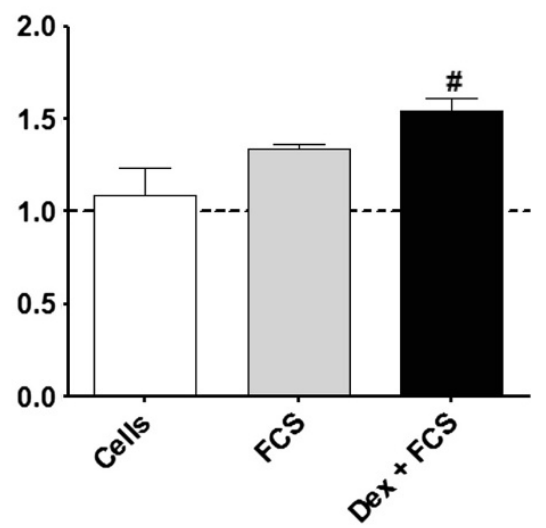

Figure 5 Effect of dexamethasone and FCS upon IncRNA expression in primary ASM cells. ASM cells were incubated with dexamethasone $\left(10^{-7} \mathrm{M}\right)$ for $1 \mathrm{~h}$ before being stimulated with FCS (2.5\%) for $24 \mathrm{~h}$. To validate the array data, the expression of LINC00882, LINC00883, c-MYC and PVT1 were confirmed by TaqMan RT-PCR. Bars represent mean \pm SEM from 9 primary ASM cells. ${ }^{* / \#} \mathrm{p}<0.05$.

cell cycle regulation such as regulation of microtubule structure, actin-filament dynamics and later stage cell cycle progression, although targeting studies need to be performed to confirm this [35-43].

lncRNAs are widely expressed and yet their importance in physiological and pathological response has only recently been elucidated $[8,44]$. They are known to have a mechanism of action upon activation of common transcription factors such as NF- $\mathrm{kB}$, Sox2, p53, Oct4 and Nanog [45]. We detected the altered expression of 29 lncRNAs following FCS stimulation, and dexamethasone + FCS treatment, including small nucleolar RNA host gene 5 (previously U50HG), known to be expressed in human B-cell lymphoma [46]; SDCBP2 antisense which is increased in expression in non-small cell lung cancer [47]; and small nucleolar host gene 11. 8 lncRNAs were increased in expression, including LINC00472 which is expressed in renal tissue [48] and small nucleolar host gene 13 (also known as DANCR) and 3
lncRNAs were differentially expressed between stimulation with FCS and those with dexamethasone and FCS which included brain cytoplasmic RNA 1 (also known as BC200) which is highly expressed in the hypothalamus [49] and is deregulated in lung cancer [50], and two novel lncRNAs; ENST00000314957 AND ENST00000420095. We validated our array data by confirming the expression of PVT1, and its transcriptional activator c-MYC. This lncRNA has been previously implicated in diabetes and cancer [51-53]. It has been demonstrated that PVT1 is overexpressed in ovarian and breast cancer cells and when this expression is inhibited by siRNAs, cell proliferation is decreased and apoptosis increased [53]. PVT1 is a downstream target of c-MYC that targets and binds PVT1, subsequently driving its transcription [52]. Interestingly both C-MYC and PVT1 are part of the same locus known to be frequently overexpressed in cancer [53] and c-MYC is an important oncogene known to increase cancer cell growth and proliferation [54]. Furthermore, it is known 


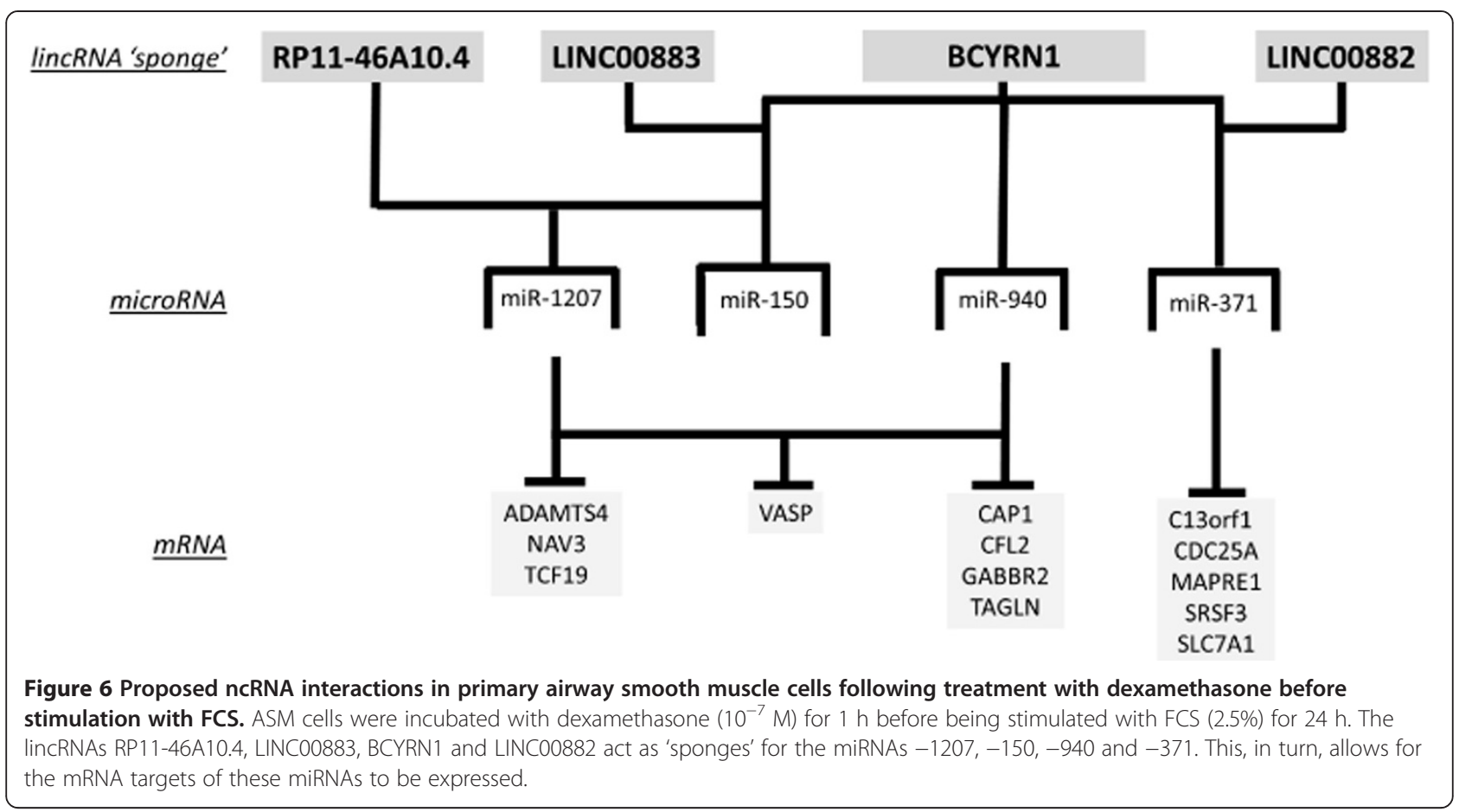

that PVT1 expression can be directly induced by p53, as well as expressing a cluster of 6 miRNAs, including miR1207-5p, which as stated above is decreased in expression in the primary ASM cells [55].

Finally, we address the possibility of lncRNAs acting as miRNA 'sponges', a concept well documented [56]. We utilized the online data base LNCipedia 2.0 (http://lncipedia.org/) and found that that 4 lncRNAs were predicted to act as miRNA 'sponges' for those miRNAs, that were seen to be decreased in expression. We propose that the lincRNAs RP11-46A10.4, LINC00883, BCYRN1 and LINC00882 act as 'sponges' for the miRNAs $-1207,-150,-940$ and -371 and that this allows for the mRNA targets of these miRNAs to be expressed, as summarised in Figure 6. Again, these interactions need to be confirmed with knock-down studies.

In summary, using a transcriptomics-based approach, we have demonstrated that primary human ASM cells have a transcript expression profile associated with an activated phenotype and have shown that these changes might, in part, be mediated through alterations in noncoding RNA expression. Clearly, it is important to confirm these observations by examining the expression of these IncRNAs in primary ASM cells from patients with asthma and then to follow up these observations by targeting specific lncRNAs (such as gain and loss-of-function studies). These studies are currently on-going.

\section{Additional file}

Additional file 1: Table S1. Up-regulated mRNAs in healthy ASM cells after stimulation with FCS. Table S2. Down-regulated mRNAs in healthy ASM cells after stimulation with FCS. Table S3. Up-regulated mRNAs in healthy ASM cells after stimulation with Dex + FCS. Table S4. Downregulated mRNAs in healthy ASM cells after stimulation with Dex + FCS. Table S5. Baseline levels of miRNAs in healthy ASM. Table S6. IncRNAs increased in expression in healthy ASM cells after stimulation with FCS. Table S7. IncRNAs decreased in expression in healthy ASM cells after stimulation with FCS. Table S8. IncRNAs increased in expression in healthy ASM cells after stimulation with Dex + FCS. Table S9. Changes in expression of IncRNAs in healthy ASM cells after stimulation with Dex + FCS.

\section{Competing interests}

The authors declare that they have no competing interests.

\section{Authors' contributions}

MMP, cultured the ASM cells, analyzed the array data, performed the RT-PCRs and drafted the manuscript. ET performed the arrays. PJA performed some of the RT-PCRS. MAL, helped analyze the array data, and helped conceive the study. DSG performed the patient biopsies. IMA \& KFA helped with writing the manuscript. All authors read and approved the final manuscript.

\section{Funding bodies}

This work was supported by grants from Asthma UK (08/041) and The Wellcome Trust (085935). It was also supported by the NIHR Respiratory Disease Biomedical Research Unit at the Royal Brompton NHS Foundation Trust and Imperial College London. KFC is a Senior Investigator of NIHR, UK. $\mathrm{MP}$ is an Imperial College Research Fellow.

\section{Author details}

${ }^{1}$ Experimental Studies, National Heart and Lung Institute, Imperial College, London \& Royal Brompton NIHR Biomedical Research Unit, Dovehouse Street, London SW3 6LY, UK. ${ }^{2}$ Respiratory Research Group, University Hospital 
of South Manchester, University of Manchester, Southmoor Road, Manchester M23 9LY, UK. ${ }^{3}$ Department of Pharmacy and Pharmacology, University of Bath, Claverton Down, Bath BA2 7AY, UK.

Received: 10 February 2014 Accepted: 28 April 2014

Published: 16 May 2014

\section{References}

1. Michaeloudes C, Chang PJ, Petrou M, Chung KF: Transforming growth factor- $\beta$ and nuclear factor E2-related factor 2 regulate antioxidant responses in airway smooth muscle cells. Am J Respir Crit Care Med 2011, 184:894-903.

2. Chang PJ, Bhavsar PK, Michaeloudes C, Khorasani N, Chung KF: Corticosteroid insensitivity of chemokine expression in airway smooth muscle of patients with severe asthma. J Allergy Clin Immunol 2012, 130:877-885.

3. Chung KF: Should treatments for asthma be aimed at the airway smooth muscle? Expert Rev Respir Med 2007, 1:209-217.

4. Halayko AJ, Amrani Y: Mechanisms of inflammation-mediated airway smooth muscle plasticity and airways remodeling in asthma. Respir Physiol Neurobiol 2003, 137:209-222.

5. Chung KF, Barnes PJ: Cytokines in asthma. Thorax 1999, 54:825-857.

6. Chung KF: Airway smooth muscle cells: contributing to and regulating airway mucosal inflammation? Eur Respir 」 2000, 15:961-968

7. Perry MM, Baker JE, Gibeon DS, Adcock IM, Chung KF: Airway smooth muscle hyperproliferation is regulated by MicroRNA-221 in severe asthma. Am J Respir Cell Mol Biol 2013, 50:7-17.

8. Taft RJ, Pang KC, Mercer TR, Dinger M, Mattick JS: Non-coding RNAs: regulators of disease. J Pathol 2010, 220:126-139.

9. Ponting $\mathrm{CP}$, Oliver PL, Reik W: Evolution and functions of long noncoding RNAs. Cell 2009, 136:629-641.

10. Clifford RL, Singer CA, John AE: Epigenetics and miRNA emerge as key regulators of smooth muscle cell phenotype and function. Pulm Pharmacol Ther 2013, 26:75-85.

11. Perry MM, Hui CK, Whiteman M, Wood ME, Adcock I, Kirkham P, Michaeloudes C, Chung KF: Hydrogen sulfide inhibits proliferation and release of IL-8 from human airway smooth muscle cells. Am J Respir Cell Mol Biol 2011, 45:746-752.

12. Mosmann T: Rapid colorimetric assay for cellular growth and survival: application to proliferation and cytotoxicity assays. J Immunol Methods 1983, 65:55-63.

13. Huang DW, Sherman BT, Lempicki RA: Systematic and integrative analysis of large gene lists using DAVID bioinformatics resources. Nat Protoc 2008, 4:44-57.

14. Huang DW, Sherman BT, Lempicki RA: Bioinformatics enrichment tools: paths toward the comprehensive functional analysis of large gene lists. Nucleic Acids Res 2009, 37:1-13.

15. Volders PJ, Helsens K, Wang X, Menten B, Martens L, Gevaert K, Vandesompele J, Mestdagh P: LNCipedia: a database for annotated human IncRNA transcript sequences and structures. Nucl Acids Res 2013, 41:D246-D251.

16. Perry MM, Moschos SA, Williams AE, Shepherd NJ, Larner-Svensson HM, Lindsay MA: Rapid changes in MicroRNA-146a expression negatively regulate the IL-1beta-induced inflammatory response in human lung alveolar epithelial cells. J Immunol 2008, 180:5689-5698.

17. Larner-Svensson HM, Williams AE, Tsitsiou E, Perry MM, Jiang X, Chung KF, Lindsay MA: Pharmacological studies of the mechanism and function of interleukin-1 beta-induced miRNA-146a expression in primary human airway smooth muscle. Respir Res 2010, 11:68.

18. Gunst SJ, Zhang W: Actin cytoskeletal dynamics in smooth muscle: a new paradigm for the regulation of smooth muscle contraction. Am J Physiol Cell Physiol 2008, 295:C576-C587.

19. Ma L, Bajic VB, Zhang Z: On the classification of long non-coding RNAs. RNA Biol 2013, 10:6-15.

20. Sahu SK, Gummadi SN, Manoj N, Aradhyam GK: Phospholipid scramblases: An overview. Arch Biochem Biophys 2007, 462:103-114.

21. Leng XF, Chen MW, Xian L, Dai L, Ma GY, Li MH: Combined analysis of mRNA expression of ERCC1, BAG-1, BRCA1, RRM1 and TUBB3 to predict prognosis in patients with non-small cell lung cancer who received adjuvant chemotherapy. J Exp Clin Cancer Res 2012, 31:25.
22. Yang W, Shen N, Ye DQ, Liu Q, Zhang Y, Qian XX, Hirankarn N, Ying D, Pan HF, Mok CC, Chan TM, Wong RWS, Lee KW, Mok MY, Wong SN, Leung AMH, Li XP, Avihingsanon Y, Wong CM, Lee TL, Ho MHK, Lee PPW, Chang YK, Li PH, Li RJ, Zhang L, Wong WHS, Ng IOL, Lau CS, Sham PC, et al: Genomewide association study in Asian populations identifies variants in ETS1 and WDFY4 associated with systemic lupus erythematosus. PLoS Genet 2010, 6:e1000841.

23. Lu D, Xie S, Sukkar MB, Lu X, Scully MF, Chung KF: Inhibition of airway smooth muscle adhesion and migration by the disintegrin domain of ADAM-15. Am J Respir Cell Mol Biol 2007, 37:494-500.

24. Hart LA, Krishnan VL, Adcock IM, Barnes PJ, Chung KF: Activation and localization of transcription factor, nuclear factor-kappaB, in asthma. Am J Respir Crit Care Med 1998, 158:1585-1592.

25. Sukkar MB, Xie S, Khorasani NM, Kon OM, Stanbridge R, Issa R, Chung KF: Toll-like receptor 2, 3, and 4 expression and function in human airway smooth muscle. J Allergy Clin Immunol 2006, 118:641-648.

26. Michaeloudes C, Sukkar MB, Khorasani NM, Bhavsar PK, Chung KF: TGF-beta regulates Nox4, MnSOD and catalase expression and IL-6 release in airway smooth muscle cells. Am J Physiol Lung Cell Mol Physiol 2010, 300:L295-L304.

27. Liu H, Zhu L, Liu B, Yang L, Meng X, Zhang W, Ma Y, Xiao H: Genome-wide microRNA profiles identify miR-378 as a serum biomarker for early detection of gastric cancer. Cancer Lett 2012, 316:196-203.

28. Schrauder MG, Strick R, Schulz-Wendtland R, Strissel PL, Kahmann L, Loehberg CR, Lux MP, Jud SM, Hartmann A, Hein A, Bayer CM, Bani MR, Richter S, Adamietz BR, Wenkel E, Rauh C, Beckmann MW, Fasching PA Circulating micro-RNAs as potential blood-based markers for early stage breast cancer detection. PLOS ONE 2012, 7:e29770.

29. Nam E, Lee M, Yim G, Kim J, Kim S, Kim S, Kim Y: MicroRNA profiling of a CD133+ spheroid-forming subpopulation of the OVCAR3 human ovarian cancer cell line. BMC Med Genet 2012, 5:18.

30. Lee JE, Hong EJ, Nam HY, Hwang M, Kim JH, Han BG, Jeon JP: Molecular signatures in response to Isoliquiritigenin in lymphoblastoid cell lines. Biochem Biophys Res Commun 2012, 427:392-397.

31. Xu K, Liang X, Cui D, Wu Y, Shi W, Liu J: miR-1915 inhibits Bcl-2 to modulate multidrug resistance by increasing drug-sensitivity in human colorectal carcinoma cells. Mol Carcinog 2013, 52:70-78.

32. Sand M, Skrygan M, Sand D, Georgas D, Gambichler T, Hahn S, Altmeyer P, Bechara F: Comparative microarray analysis of microRNA expression profiles in primary cutaneous malignant melanoma, cutaneous malignant melanoma metastases, and benign melanocytic nevi. Cell Tissue Res 2013, 351:85-98.

33. Solberg OD, Ostrin EJ, Love Ml, Peng JC, Bhakta NR, Hou L, Nguyen C, Solon M, Nguyen C, Barczak AJ, Zlock LT, Blagev DP, Finkbeiner WE, Ansel KM, Arron JR, Erle DJ, Woodruff PG: Airway epithelial miRNA expression is altered in asthma. Am J Respir Crit Care Med 2012, 186:965-974.

34. Karagiannis G, Weile J, Bader G, Minta J: Integrative pathway dissection of molecular mechanisms of moxLDL-induced vascular smooth muscle phenotype transformation. BMC Cardiovasc Disord 2013, 13:4

35. Wegener S, Hampe W, Herrmann D, Schaller HC: Alternative splicing in the regulatory region of the human phosphatases $C D C 25 \mathrm{~A}$ and $C D C 25 C$. Eur J Cell Biol 2000, 79:810-815.

36. Su LK, Qi Y: Characterization of Human MAPRE Genes and Their Proteins. Genomics 2001, 71:142-149.

37. Zahler AM, Lane WS, Stolk JA, Roth MB: SR proteins: a conserved family of pre-mRNA splicing factors. Genes Dev 1992, 6:837-847.

38. Closs El, Boissel JP, Habermeier A, Rotmann A: Structure and function of Cationic amino Acid Transporters (CATs). J Membrane Biol 2006, 213:67-77.

39. Matviw $H, Y u$ G, Young D: Identification of a human cDNA encoding a protein that is structurally and functionally related to the yeast adenylyl cyclase-associated CAP proteins. Mol Cell Biol 1992, 12:5033-5040.

40. Thirion C, Stucka R, Mendel B, Gruhler A, Jaksch M, Nowak K, Binz N, Laing NG, Lochmüller H: Characterization of human muscle type cofilin (CFL2) in normal and regenerating muscle. Eur J Biochem 2001, 268:3473-3482.

41. Camoretti-Mercado B, Forsythe SM, LeBeau MM, Espinosa R III, Vieira JE, Halayko AJ, Willadsen S, Kurtz B, Ober C, Evans GA, Thweatt R, Shapiro S, Niu Q, Qin Y, Padrid PA, Solway J: Expression and Cytogenetic Localization of the Human SM22 Gene (TAGLN). Genomics 1998, 49:452-457.

42. Haffner C, Jarchau T, Reinhard M, Hoppe J, Lohmann SM, Walter U: Molecular cloning, structural analysis and functional expression of the 
proline-rich focal adhesion and microfilament-associated protein VASP. EMBO J 1995, 14:19-27.

43. Ku DH, Chang CD, Koniecki J, Cannizzaro LA, Boghosian-Sell L, Alder H, Baserga R: A new growth-regulated complementary DNA with the sequence of a putative trans-activating factor. Cell Growth Differ 1991, 2:179-186.

44. Kung JTY, Colognori D, Lee JT: Long Noncoding RNAs: Past, Present, and Future. Genetics 2013, 193:651-669.

45. Guttman M, Amit I, Garber M, French C, Lin MF, Feldser D, Huarte M, Zuk O, Carey BW, Cassady JP, Cabili MN, Jaenisch R, Mikkelsen TS, Jacks T, Hacohen N, Bernstein BE, Kellis M, Regev A, Rinn JL, Lander ES: Chromatin signature reveals over a thousand highly conserved large non-coding RNAs in mammals. Nature 2009, 458:223-227.

46. Tanaka R, Satoh H, Moriyama M, Satoh K, Morishita Y, Yoshida S, Watanabe T, Nakamura Y, Mori S: Intronic U50 small-nucleolar-RNA (snoRNA) host gene of no protein-coding potential is mapped at the chromosome breakpoint t(3;6)(q27;q15) of human B-cell lymphoma. Genes Cells 2000, 5:277-287.

47. Sanchez-Palencia A, Gomez-Morales M, Gomez-Capilla JA, Pedraza V Boyero L, Rosell R, Fárez-Vidal ME: Gene expression profiling reveals novel biomarkers in nonsmall cell lung cancer. Int J Cancer 2011, 129:355-364.

48. Song X, Di Giovanni V, He N, Wang K, Ingram A, Rosenblum ND, Pei Y: Systems biology of autosomal dominant polycystic kidney disease (ADPKD): computational identification of gene expression pathways and integrated regulatory networks. Hum Mol Genet 2009, 18:2328-2343.

49. Watson JB, Sutcliffe JG: Primate brain-specific cytoplasmic transcript of the Alu repeat family. Mol Cell Biol 1987, 7:3324-3327.

50. Chen W, Bocker W, Brosius J, Tiedge H: Expression of neural BC200 RNA in human tumours. J Pathol 1997, 183:345-351.

51. Alvarez ML, DiStefano JK: Functional characterization of the Plasmacytoma Variant Translocation 1 gene (PVT1) in diabetic nephropathy. PLOS ONE 2011, 6:e18671.

52. Carramusa L, Contino F, Ferro A, Minafra L, Perconti G, Giallongo A, Feo S: The PVT-1 oncogene is a Myc protein target that is overexpressed in transformed cells. J Cell Physiol 2007, 213:511-518.

53. Guan Y, Kuo WL, Stilwell JL, Takano H, Lapuk AV, Fridlyand J, Mao JH, Yu M, Miller MA, Santos JL, Kalloger SE, Carlson JW, Ginzinger DG, Celniker SE, Mills GB, Huntsman DG, Gray JW: Amplification of PVT1 contributes to the pathophysiology of ovarian and breast cancer. Clin Cancer Res 2007, 13:5745-5755

54. Dang CV: c-Myc target genes involved in cell growth, apoptosis, and metabolism. Mol Cell Biol 1999, 19:1-11.

55. Barsotti AM, Beckerman R, Laptenko O, Huppi K, Caplen NJ, Prives C: p53-dependent Induction of PVT1 and miR-1204. J Biol Chem 2012, 287:2509-2519.

56. Hu W, Alvarez-Dominguez JR, Lodish HF: Regulation of mammalian cell differentiation by long non-coding RNAs. EMBO Rep 2012, 13:971-983.

doi:10.1186/1465-9921-15-58

Cite this article as: Perry et al:: Role of non-coding RNAs in maintaining primary airway smooth muscle cells. Respiratory Research 2014 15:58.

\section{Submit your next manuscript to BioMed Central and take full advantage of:}

- Convenient online submission

- Thorough peer review

- No space constraints or color figure charges

- Immediate publication on acceptance

- Inclusion in PubMed, CAS, Scopus and Google Scholar

- Research which is freely available for redistribution

Submit your manuscript at www.biomedcentral.com/submit
C BioMed Central 